Article

\title{
The Hybrid Spatialities of Post-Industrial Beijing: Communism, Neoliberalism, and Brownfield Redevelopment
}

\author{
Nyuying Wang ${ }^{1}$, Oleg Golubchikov ${ }^{2,3}{ }^{-0}$, Wei Chen ${ }^{4,5}$ and Zhigao Liu ${ }^{4,5, *}$ \\ 1 College of Urban and Environmental Sciences, Peking University, Beijing 100871, China; \\ wangny@pku.edu.cn \\ 2 School of Geography and Planning, Cardiff University, Glamorgan Building, King Edward VII Avenue, \\ Cardiff CF10 3WA, UK; golubchikovo@cardiff.ac.uk \\ 3 Visiting Professor, Department for Spatial Development and Regional Studies, National Research University \\ Higher School of Economics, 101000 Moscow, Russia \\ 4 Key Laboratory of Regional Sustainable Development Modelling, Institute of Geographic Sciences and \\ Natural Resources Research, Chinese Academy of Sciences, Beijing 100101, China; chenw@igsnrr.ac.cn \\ 5 School of Resources and Environment, University of Chinese Academy of Sciences, Beijing 100049, China \\ * Correspondence: liuzhigao@igsnrr.ac.cn; Tel.: +86-10-64889529; Fax: +86-010-64889302
}

Received: 22 April 2020; Accepted: 16 June 2020; Published: 19 June 2020

check for updates

\begin{abstract}
While the redevelopment of urban brownfield sites in China has received much attention, the role of political ideology in this process is usually downplayed or sidelined to a set of stylized assumptions. This paper invites giving a greater analytical focus to the evolving and nonorthodox nature of China's politico-ideological model as a factor shaping urban change and redevelopment. The paper provides an analytical framework integrating multi-level and evolutionary perspectives while exploring the experiences of the formation and post-industrial redevelopment of brownfield sites in Beijing. The analysis demonstrates that neoliberal economic policies and the communist political doctrine are co-constitutive in the production of China's post-industrial urban space. This produces a sense of spatial hybridity that combines and co-embeds what may be assumed to be mutually exclusive.
\end{abstract}

Keywords: urban brownfield; post-industrial; hybrid spatiality; Beijing; Fatou

\section{Introduction}

Issues pertaining to brownfield redevelopment in post-industrial urban contexts have recently gained broad attention across the world [1-4]. China has not stayed outside these processes. Despite its overall trajectories of rapid industrialization (rather than deindustrialization), the industrial structure does change in China-and rather rapidly so-with the consequence being that many industrial assets experience quick depreciation. In addition, the sheer size of the non-manufacturing economy is also radically expanding in China. All this has spatial consequences. For example, while inner cities experience commercialization and increases in land rents, industries are forced to move from central to more peripheral locations. What these industries leave behind are often abandoned, and contaminated sites, or "brownfields". Consequently, brownfield redevelopment and land reuse have become political priorities in China's cities.

Literature on urban brownfield has ranged in its concerns broadly to encompass, for example, debates about drivers and barriers of brownfield redevelopment [2,3,5-7], mechanisms and stakeholders involved in different phases of redevelopment process [1,8,9], potential reuses $[10,11]$, and evaluations of impacts and benefits of redevelopment [12-15]. Furthermore, brownfield regeneration is often seen 
from the perspective of the economic logic of neoliberalism underpinning contemporary urban change. Existing inquiries into China's transformation and urban restructuring also emphasize neoliberalism and market mechanisms, while considering the still-prominent communist ideology as mostly an ideological 'noise', which is somehow external to urban restructuring per se [16].

In this paper, we want to revisit the interplay between political and economic factors in urban change and redevelopment in Beijing. Using brownfields as an insightful lens, we want to demonstrate that, in the case of China, neoliberal strategies and communist ideologies are both actively combined in the production of urban space. While it is the neoliberal logic that drives today's pro-growth and pro-globalization "extraverted" urban agendas [17], the influences of the communist ideology on urban space are still strong and appear both as historical/legacy spaces and as ongoing/active spaces. Here, legacy spaces are being subsumed and maneuvered into today's requirements, but these requirements are being shaped not only by the logics of neoliberalism, but also (and quite actively so) by the communist doctrine. This produces a sense of spatial hybridity that combines and co-embeds ideological elements that may be assumed to be mutually contradictory.

The empirical foundation of the paper is based on field studies carried out in 2018-2019 in Fatou, an area in Beijing that used to be a chemical manufacturing complex under state industrialism, but which has more recently been converted into a residential area. It is an emblematic case for the rise and fall of industrial areas in Beijing, and can illustrate the drivers of urban change. The story of Fatou involves the construction of a socialist manufacturing enterprise under state-led industrialism in the 1950s-1960s, the expansion of the industrial zone in the 1970s-1990s, and its subsequent fall under emerging neoliberalism. We review the evolution of Fatou in these three distinctive periods as a multi-level "momentum" - involving the projection and interplay of the national-, city-, and district-level processes (Table 1). A number of local policy documents, government publications, and media reports have supported our analysis.

Table 1. Urban development in Beijing.

\begin{tabular}{|c|c|c|c|}
\hline $\begin{array}{l}\text { City Development } \\
\text { Stage }\end{array}$ & $\begin{array}{l}\text { 1950s-1960s } \\
\text { Urbanization Through } \\
\text { Industrialization }\end{array}$ & $\begin{array}{c}\text { Late 1970s-1990s } \\
\text { Accelerated Urbanization and } \\
\text { Decentralization }\end{array}$ & $\begin{array}{l}\text { 2000s-2010s } \\
\text { Restructuring in Post-Reform Period }\end{array}$ \\
\hline $\begin{array}{l}\text { International } \\
\text { context }\end{array}$ & $\begin{array}{l}\text {-Modeling development after the } \\
\text { Soviet Union; } \\
\text {-Industrial geography. }\end{array}$ & $\begin{array}{l}\text {-Neoliberalism and globalism; } \\
\text {-Borrowing planning ideas and } \\
\text { experience from market economies. }\end{array}$ & $\begin{array}{l}\text {-Global city system; } \\
\text {-Global city-regionism. }\end{array}$ \\
\hline State-level context & $\begin{array}{l}\text {-State industrialization puts } \\
\text { priority on heavy industry; } \\
\text {-Administrative allocation of land } \\
\text { and danwei system providing } \\
\text { housing and social services. }\end{array}$ & $\begin{array}{c}\text {-Domestic reforms from a centrally } \\
\text { planned to a market-oriented system; } \\
\text {-Fiscal and administrative } \\
\text { decentralization; } \\
\text {-Urban land system reform and land } \\
\text { leasehold market } \\
\text { established;-Housing reform. }\end{array}$ & $\begin{array}{l}\text {-Coordinated development of the } \\
\text { Beijing-Tianjin-Hebei; } \\
\text {-Promises under the world } \\
\text { heritage conservation. }\end{array}$ \\
\hline $\begin{array}{l}\text { City-level context } \\
\text { (Beijing) }\end{array}$ & $\begin{array}{l}\text {-Socialist productive cities; } \\
\text {-Heavy industry-led policies; } \\
\text {-Planning and construction of } \\
\text { industrial areas. }\end{array}$ & $\begin{array}{l}\text {-Policies for "national political and } \\
\text { cultural center" in } 1983 \text { and "modern } \\
\text { international city" in 1992; } \\
\text {-'Decentralized conglomerates' spatial } \\
\text { pattern for industries; } \\
\text {-Industrial park and economic and } \\
\text { technological development zone as a } \\
\text { key spatial strategy for industries; } \\
\text {-Industrial relocation policies. }\end{array}$ & $\begin{array}{l}\text { - 'World city' planning proposal } \\
\text { in 2000s; } \\
\text {-2008 Beijing Olympic Games; } \\
\text {-Industrial upgrading and } \\
\text { intra-regional relocation; } \\
\text {-Renovation Program and Public } \\
\text { Housing Program. }\end{array}$ \\
\hline $\begin{array}{l}\text { District-level } \\
\text { context (Fatou) }\end{array}$ & $\begin{array}{l}\text {-Rural landscape before 1950s; } \\
\text {-Chemical Industrial Area } \\
\text { construction in 1950s; } \\
\text {-Residential community built up; } \\
\text {-Incorporated into city } \\
\text { management in 1960s. }\end{array}$ & $\begin{array}{c}\text {-Forms an area surrounding a } \\
\text { Z-shaped main road in 1970s; } \\
\text {-Destination of industrial in-migration } \\
\text { from the central city in 1980s; } \\
\text {-Incorporated into central urban area, } \\
\text { became an industry out-migration } \\
\text { place in 1990s. }\end{array}$ & $\begin{array}{c}\text {-The removal of chemical industrial } \\
\text { enterprises; } \\
\text {-Brownfield assessment and } \\
\text { remediation; } \\
\text {-Planning and redevelopment through } \\
\text { property development and heritage } \\
\text { protection mechanisms. }\end{array}$ \\
\hline
\end{tabular}


In what follows, we start with developing our conceptual approach by reviewing literature on brownfield redevelopment, neoliberalization, and continuity and change in urban spatial structures. We then provide an introduction to Beijing's transition from a socialist productive city into a post-industrial metropolis. By establishing an analysis framework that combines multi-level and evolutionary perspectives, further inquiries about the hybridity of active communist political ideology and operational neoliberal economic policies are conducted with the empirical case of Fatou and its formation as, first, an industrial and, then, post-industrial area.

\section{Exploring Brownfield Redevelopment}

The recycling of formerly industrial land, especially currently unused or underused land, has been long at the center of policy and academic literature. This has been an important issue in regions with a history of deindustrialization, like in Europe and North America. Both site-specific attributes and structural factors determine the emergence and character of brownfields and their destinies. As for the contextual factors, extant studies suggest that property relationships, geographical location, type of industrial activity, and levels of contamination are among attributes influencing the trajectories of brownfield development and redevelopment [18-20]. However, brownfields are certainly a product of broader processes and shifts. These multi-level factors include deindustrialization and economic transition (beginning as early as the 1970s in Western Europe and in the 1990s in post-socialist Eastern and Central Europe), international/interregional industrial migration, investment deficit in old industrial places [4,21,22], innovation and organizational shifts in industrial processes, environmental policies, commercialization, and increases in land rents in inner cities (as in the 2000s in China) [23]. Moreover, negative impacts imposed by manufacturing on the environment and health conditions as well as extensive land-use footprints are among factors that put further pressures on traditional urban industrial areas $[16,24,25]$.

There is a broad consensus that brownfield redevelopment can be part of the larger efforts to address land use problems, improve social cohesion, and create favorable economic conditions [26,27]. There are yet variations in motivations, concerns, and priorities among different regions, as can be seen across Europe. For example, making land available for urban development is often prioritized in densely populated and economically advanced countries (e.g., the UK, Germany, Belgium) [28-30]. For regions with relatively low population density (Finland, Ireland, Sweden, and Norway), the focus is often placed on dealing with pollution and contamination [31-33]. Countries in Southern and Central Europe have considered brownfield redevelopment as a driver of economic regeneration [34-36].

Brownfield redevelopment constitutes different phases, requiring enormous endeavors from multiple stakeholders with potentially divergent interests. However, almost everywhere, the increasing attention to the nexus between brownfield redevelopment, environmental and health safety, and broader sustainability makes brownfields subject to extensive public interventions. Though circumstances vary among countries, incentives and steer given by governments play an essential role, no matter whether strategies are market-based or state-led [6,37]. Public initiatives may involve regulation, technical standards, funding supports, and planning policies, among other forms [3,38]. Taking the US as an example, as early as in the 1980s, brownfield liabilities fell under the federal and state legislative framework (the Comprehensive Environmental Response, Compensation, and Liability Act-CERCLA)—although such a heavy-handed regulatory approach was criticized for discouraging private parties' involvement. The Environmental Protection Agency's Brownfield Program in the 1990s and the Small Business Liability Relief and Brownfields Revitalization Act of 2002 were further important vehicles promoting brownfield redevelopment in the US [3,6,39]. In urban China, the state has quite a direct leverage, as brownfields generally emerge from the outmigration of formerly state-owned enterprises (SOEs), so that key stakeholders involved in their redevelopment are SOEs themselves as well as local governments and developers [5,40].

Brownfields may be converted into a range of land uses, including residential buildings, creative industrial zones, pocket parks, museums, leisure places, and others [41-43]. In the US, the most 
commonly reported reuses include commercial uses, green space, mixed use, residential use, and industrial use [44]. As another example, according to Osman et al. [4], new functions of brownfields in Czechia are predominantly civic amenities, mixed use, and industry. In the UK, the reuse of brownfield land for housing has been a strategic land-use policy instrument since the 1990s [45]. Brownfield redevelopment is widely acclaimed for bringing a broad range of benefits to society, for instance, providing land for new housing, public spaces, and facilities, as well as new and alternative economic and employment opportunities, with the consequent expansion of tax bases and elimination of environmental and health threats [11,45-49].

In China's major cities, residential use, creative industrial zone uses, and heritage preservation are popular functions for converted brownfields. Real estate development and the promise of quick profit realization have certainly driven many landmark redevelopment projects, like the redevelopment of Yangpu industrial area in Shanghai [50]. While many such projects involve a complete removal of all of the industrial uses, with the rise of the middle class and a cultural shift towards a post-modern society, the industrial aesthetics are now also increasingly monetized in urban China. Thus, industrial heritage and creative industrial parks, such as Factory 798 in Beijing or Red Town Creative Park in Shanghai, have gained popularity [41,51]. Policy discourse of the heritagization of brownfields particularly accelerated after the 2006 Wuxi Forum on the conservation of cultural heritage and the release of China Industrial Heritage Protection List [52].

Generally, studies converge on that brownfield redevelopment is a highly contextualized issue, whose complexity relies in the interactions among many sets of factors. However, the role of government ideology as one of major underlying factors steering brownfield formation and redevelopment has so far attracted little direct attention. Since the emergence of the brownfield redevelopment agenda in China coincided with neoliberalization, it is generally assumed that it is the logic of the latter that shapes the institutional conditions, processes, and outcomes of brownfield redevelopment. This is, however, not only to overlook the historicity of brownfield space (that is, the ideological conditions under which the brownfields were produced in the first place and the interplay of these conditions with today's modalities), but also to overlook the enduring influence of the Chinese communist doctrine on the production of urban space. In other words, we need to start unpacking the hybrid spatialities of the Chinese post-industrial urban landscape.

\section{Neoliberalization and Hybridity}

Hybridity is a concept that has been actively debated in fields such as cultural studies and post-colonialism, but it has also found its way into urban and geographical studies. Golubchikov et al. [53] use hybridity for critiquing the spatiality of post-socialist transition. Their research understands post-socialism as a process of the subsumption of inherited spatial systems into the logic of capital, so that pre-existing urban space is transformed into the new relationships of capitalist production despite its continuing material legacies. What was originally produced to serve a socialist political economy and the ideology of egalitarian redistribution is now institutionally transformed-often with no change in its material appearance- to serve the now very different logic of capital accumulation. The very same urban system that previously served as the infrastructure of spatial and social justice, under the new politico-economic system, even where remaining the same in its appearance and function, turns into the infrastructure of (uneven) capital accumulation and its socially differentiating consequences [53,54]. This re-institutionalizing of space also provides a sense of spatial hybridity, where different ideological origins of space are blended together to make a union that functions according to the new requirements of the political economy of the day (see also [55]).

In China, beyond the spatial legacy of the "pure" socialist decades, urban space continues to be under the influences of a "mixed" model of today, in which communism is still decisively an integral ideological part. According to $\mathrm{Wu}$ [56], the Chinese model of neoliberalization consists of two seemingly contradictory yet, in reality, complementary elements: A market mechanism and strong state control. However, the theoretical perspective of neoliberal urbanism often tends to 
over-simplify issues in the state-market relationship as "diametrically opposed principles of social organization" [57]. Following Golubchikov et al. [53], we rather suggest that "hybrid spatiality" is a perspective to overcome this binary of "pure" models and understand the mutual embeddedness of the political ideology of communism and the economic ideology of neoliberalism in producing China's post-industrial urban space. Contrary to the other ex-socialist spaces in Eastern Europe, it is not only that socialist legacies are remolded as infrastructure of capital accumulation, but the market mechanism is also "filtered through" the active but evolving ideology of communism. This adds a degree of complexity to the sense of hybridity in the production of new urban space in China.

This filtrating of market forces is the domestication of global neoliberalism in China, achieved through large-scale but gradual transformations. While the market pricing mechanism was introduced and political-economic power was given to the localities, essential ideological elements (such as state-owned land tenure, powerful state intervention, the binary structure of urban and rural areas) have not been overturned $[23,58]$. Such institutional arrangements have direct reflections on the practice of urban development. Importantly, urban planning, especially master plan at the municipal level, remains a powerful order of direct guidance to urban development activities [59].

After the establishment of the socialist China in 1949, following the model of the Soviet Union, the system included public land ownership and a single administrative system of urban land-use allocation. Urban planning acted as an extension tool for the five-year national economic development plans and served mainly to territorialize national industrial programs. A model of socialist urbanism was established, which contained, for example, the emblematic danwei system-a form of the socio-spatial organization of urban space into communities of workers, centered on industrial production facilities $[60,61]$, and aiming to reach the goal of egalitarianism. However, keeping industrial production in a city center imposes serious challenges to urban livability and sustainability. The priority given to production over living infrastructure also caused its problems, such as a shortage of housing.

Following a neoliberal turn in the advanced capitalist world in the late 1970s, urban China also experienced profound 'neoliberal shifts' [62], where 'neoliberal elements interdigitated with authoritarian centralized control' [58] (p. 120) to form a particular path. As a result, Chinese urbanization was reshaped. Land commodification, as a salient restructuring force in post-reform urbanization, released previous non-circulating assets into capital accumulation. This is a mechanism of neoliberalism that began in 1988 with a milestone distinction between land ownership and land use rights, followed by the legitimization of paid land use that allowed urban land use rights to be leased at a profit for a period of time. As a consequence, land has become the main financial asset for local governments. The introduction of a tax-sharing system in 1994 was another seminal event that reshaped the power structure between central and local levels and further promoted urbanization, with much responsibility given to urban governance. This situation has combined capital and state power to transform China-a process that is often conceptualized using Western theories as a Chinese socialist pro-growth machine [63,64].

In the post-reform era, the locality was actively integrated into capital accumulation and intercity competition, while urban space was gradually remolded to follow a capital logic. Urban space has been incorporated into various politics of accumulation, such as inner city displacement in the early 1990s, development zone fever in the late 1990s, city branding, and new town construction in the mid-2000s [23,65]. Consequently, urban planning was utilized as a tool for urban growth. In other words, urban planning has left its service to industrialism and began to serve entrepreneurial urbanism. Nevertheless, the municipal master plan (essentially a comprehensive land-use-oriented plan) still guides and controls investments by providing a spatial 'blueprint' [59]. Critics have noted that the neoliberal perspective of the transformation of planning in China overlooks many elements (for instance, the manner and degree of state intervention and values of the socialist ideology) inherited from the socialist system [66-68]. Additionally, the spatial structure has continuity. Beijing is an example of long-term politics and infrastructure policies that reinforce its monocentric spatial structure. 
However, even more fundamentally, egalitarianism, as a long-term goal, has not been abandoned in China, at least in theory. The communist ideology and values (such as common wealth, social equity, collectivism), as well as some socialist institutional arrangements, are still embedded in China's urban change [16]. As a result, the process of localization of neoliberalism has confronted institutional resistance and constraints.

For instance, the system of tender, auction, and listing (TAL, zhao pai gua) was introduced in 1990 to enhance the marketization process of urban land. Until 2004, it was mandatory that all land granted for commercial use was transacted through the TAL process. However, in Beijing, most land transactions continue to be conducted via administrative allocation and negotiation. Another example includes the welfare provision transformation policy on housing reform (SC (1998) No.23), which officially abolished the work-unit-based housing provision system in 1998 and paved the way for the marketization of housing. However, a new form has emerged called 'new danwei', which takes the merits of socialist danwei [69].

Below, we consider the dynamics of a brownfield as a mirror of the broader macroeconomic changes and transforming ideology. We seek to understand the changing spatial fabric of brownfield sites as a result of economic restructuring, changing urban governance, and social-economic development philosophies that are essentially affected by ideological transformation. Table 1 provides an overview of our analytical framework as a multi-level process, basing on the experiences of Beijing and its brownfield areas. We will now turn to discussing these experiences in more detail.

\section{Transition from an Industrial City to a Post-Industrial Metropolis}

After the Communist party came to power in 1949 and established the socialist command economy, Beijing was transformed from an emerging 'consumer city' into a socialist 'productive city' [70,71]. Modernizing China's industrial system was a national strategy, and, at that time, urban planning acted as a "territorial organization of productive force" to facilitate economic priorities.

To emphasize the priority of heavy industry, plans for industrial areas in Beijing emerged in the 1954 version of the master plan, The Key Points of the Draft Plan for the Renovation and Expansion of Beijing, and the document The Key Points of Beijing Urban Development. Considering the densely populated urban core (area within today's Second Ring Road) and the physical density of the administrative institutions, large manufacturing industry areas were planned and mainly constructed in the area just outside the core built-up area at the time--between today's Third and Fifth Ring Road.

Since then, while industrialization was successfully achieved, over time, it not only caused urban population growth, but also the emergence of various tensions with regard to the social functioning of Beijing. As Beijing continued to expand outward and beyond those original industrial areas, the latter also found themselves being "moved" from being at a far periphery to becoming more and more part of the inner city. This produced issues with environmental pollution and the necessity to "leapfrog" with new urban developments and infrastructure further and further from the historic core. At the same time, the powerful industrial departments were not interested in vacating those areas and engaging in a costly removal of factories. Apart from the fixed costs of the productive facilities, that would also mean a removal of the whole settlement system of their workers.

The macroeconomic conditions in the 1980s encouraged the development of services and light industries and brought about attempts to adapt the socialist productive city. To address the shortage of urban services and poor infrastructure in the early 1980s, Beijing reoriented itself away from a "productive city" and towards displaying an image of a renowned historical and cultural city. A new "dispersed constellations" pattern was proposed to guide population growth, with some related Soviet ideas of urban planning, such as "satellite towns", and heritage preservation introduced in the 1982 master plan.

Further market-oriented reforms in the 1990s contributed to Beijing's rapid transformation into an "international city". This process sped up removing polluting and energy-intensive activities, especially since the municipal state set the hi-tech industry as one of its core goals in 1997. A new industrial 
geography formed in the process of industrial redistribution across the city, with development zones and high-tech parks emerging as its spatial carriers. Following the accession of China to the WTO (Word Trade Organization) in 2001, Beijing became a hotspot of foreign investment.

Preparations for the 2008 Olympic Games catalyzed a new round of urban development in terms of infrastructure development (new subway lines, light rails, high-speed train to the airport, fifth and sixth ring roads) and a new round of reterritorialization [23,71,72]. For example, rural counties in the outer suburbia were administratively changed into Beijing's urban districts in the early 2000s to pave the way for the land needed for Beijing's expansion [72]. A new industrial geography eventually formed across the metropolitan area. For example, if Chaoyang District (an eastern suburb, which also contains the Fatou area discussed below) was the main manufacturing cluster in 1985, by the end of 2004 , because of promotion of polycentric development in outer suburban areas, Daxing and Shunyi New Town had become the main area of upgraded manufacturing [73]. The municipal state published acts to enforce the out-migration of manufacturing in the name of the environment and national image (the Beijing Olympic Games were seen as a window onto the world). In 2000, following environmental considerations and the 'Green Olympic Games' slogan, the city planned to reduce the ratio of industrial land use to $7 \%$ within five years to solve the problem of its severe air and noise pollution. The core idea behind these initiatives, as well as the accompanying redevelopment processes, was to increase land values for local revenue and to further make room for global investment among intensified intra-city competition and place-branding [73].

After the 2010s, this de-manufacturing process went beyond Beijing's provincial boundaries. Beijing now claimed itself as a global city, while the "coordinated development of the Beijing-Tianjin-Hebei region" was raised to the status of a national strategy. This strategy accelerated the dispersal of the functions that were not considered essential for the capital city. Following a long decline of the city manufacturing industry and the growing service sector and knowledge economy, the sector structure in Beijing has dramatically changed since 1980 (Table 2).

Table 2. Economic structure in Beijing (\%).

\begin{tabular}{ccccccc}
\hline \multirow{2}{*}{ Year } & \multicolumn{3}{c}{ GDP } & \multicolumn{3}{c}{ Employment } \\
\cline { 2 - 7 } & $\begin{array}{c}\text { Primary } \\
\text { Industry }\end{array}$ & $\begin{array}{c}\text { Secondary } \\
\text { Industry }\end{array}$ & $\begin{array}{c}\text { Tertiary } \\
\text { Industry }\end{array}$ & $\begin{array}{c}\text { Primary } \\
\text { Industry }\end{array}$ & $\begin{array}{c}\text { Secondary } \\
\text { Industry }\end{array}$ & $\begin{array}{c}\text { Tertiary } \\
\text { Industry }\end{array}$ \\
\hline 1980 & 4.4 & 68.7 & 26.9 & 24.4 & 42.8 & 32.8 \\
1990 & 8.7 & 52.3 & 39.0 & 14.5 & 44.9 & 40.6 \\
2000 & 2.5 & 32.4 & 65.1 & 11.8 & 33.6 & 54.6 \\
2010 & 0.9 & 23.5 & 75.7 & 6.0 & 19.7 & 74.4 \\
2018 & 0.4 & 18.6 & 81.0 & 3.7 & 14.7 & 81.6 \\
\hline
\end{tabular}

Data source: National Bureau of Statistics, China Statistical Yearbook.

\section{Urbanization through Industrialization}

The Fatou area is located in the Chaoyang District in the southeast of Beijing's central city. This area used to be a chemical manufacturing complex (industrial production area with residential community) located in exurbia Beijing. It was consequently incorporated into the inner city of Beijing as one of ten major residential constellations, located within a $10-20 \mathrm{~km}$ radius circle around the city center. Fatou is located approximately $12 \mathrm{~km}$ southeast of Tiananmen Square (the city center) between the Fourth Ring Road and the Fifth Ring Road, $9 \mathrm{~km}$ south of the CBD (Central Business District) area, $10 \mathrm{~km}$ southwest of Tongzhou New Town (a municipal administrative sub-center), and $6 \mathrm{~km}$ north of Yizhuang New Town (Beijing's economic-technological development area) (see Figure 1). After recent redevelopment, Fatou now represents a mixed-use functional complex (which combines residential, industrial, heritage preservation, and cultural tourism). The area also acts as a key node of the municipal master plan, as well as a strategic nexus of the Beijing-Tianjin-Hebei Region. 


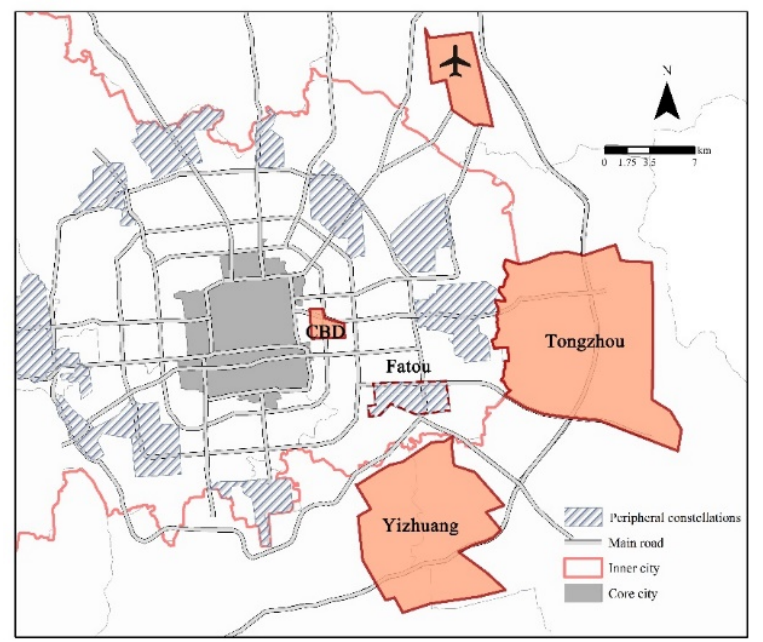

Figure 1. Location of the Fatou area in relation to Beijing's spatial structure.

The historical rise of Fatou as an industrial zone and its eventual decline and redevelopment are indicative of the interplay of ideological factors, industrial shifts, and local politics. Since 1949, urban development was controlled by a series of national five-year economic plans [74]; urban planning served as a tool to territorialize industrial projects after economic plans. In response to the national socialist industrialization strategy in the 1950s, the planning and construction of several industrial zones was first proposed between 1953 and 1954 with reference to Moscow's Plan of 1935 [66]. In 1958, the document Principles for Urban Development (Draft) named the socialist capital of Beijing a modernized industrial base that mainly focused on iron and steel, engineering, electric manufacturing, and the organic synthetic chemistry industry. After the functions of the city were confirmed, the productive forces were territorialized according to the development priorities and the functioning zoning planning (Figure 2). At the same time, planners tried to integrate Soviet planning approaches, such as satellite towns, into Beijing's practice. A number of satellite towns centered on large-scale SOEs (state-owned enterprises) were built up in suburban areas, linked via ring roads and radial roads and separated by green belts [66]. Borrowed from the Soviet concept of a micro-district (mikrorayon in Russian), the unique Chinese danwei system was formed based on a limited journey to work $[61,66]$.

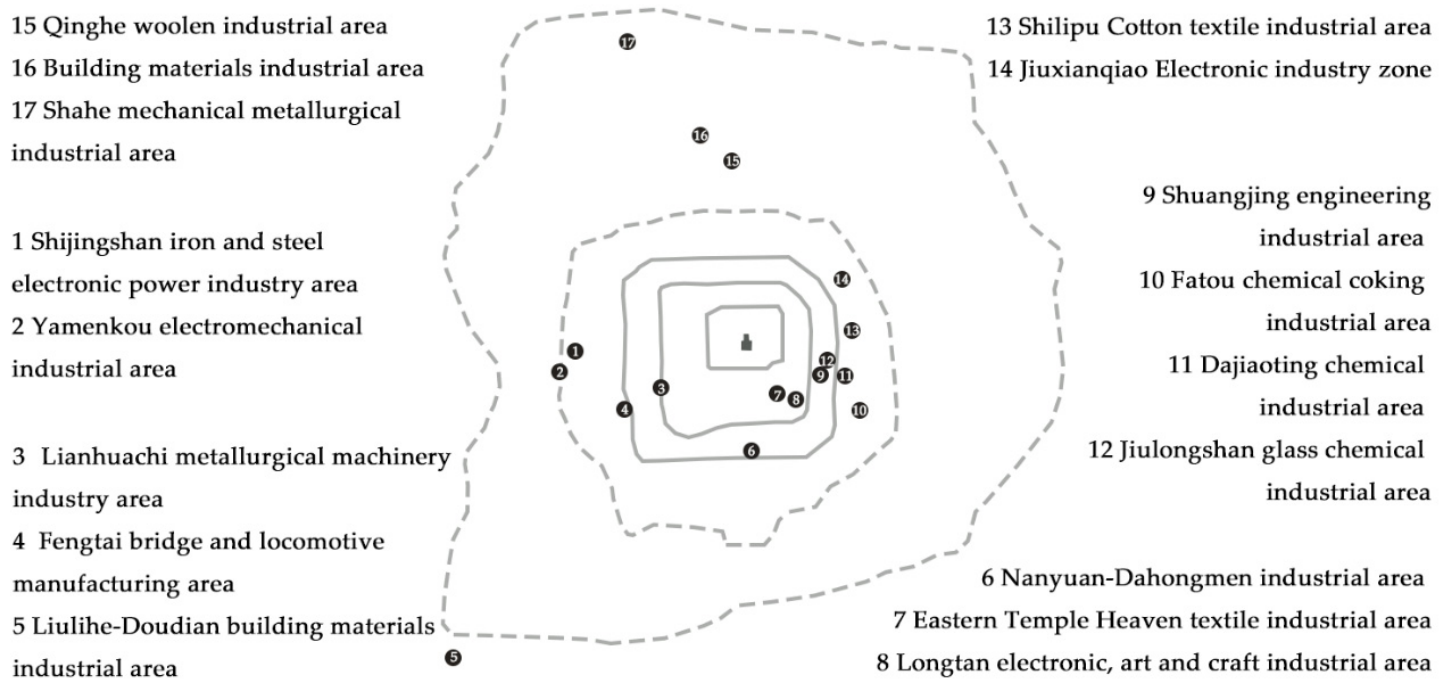

Figure 2. Positions of the industrial areas in the 1950s-1960s. Source: Adapted from Beijing Planning Chorography [75] (pp. 160-179). 
Fatou, a previously rural area, emerged as one of the new industrial sites. According to planning from 1958, Fatou was established as a chemical industrial zone in the south-eastern suburb (Fatou area) occupying farmland in the Nanmofang Township and the Wangsiying Township. In March 1959, on the original site of a nitrogen fertilizer plant and an electrolyte plant, the Beijing coking chemical plant was established as a tribute project for the tenth anniversary of the establishment of the People's Republic of China (Figure 3). This plant provided coal gas as the energy resource for Beijing's residential and office buildings. Subsequently, a dyestuff plant and many other small-sized chemical-industrial-related plants moved into the area to form an industrial agglomeration.

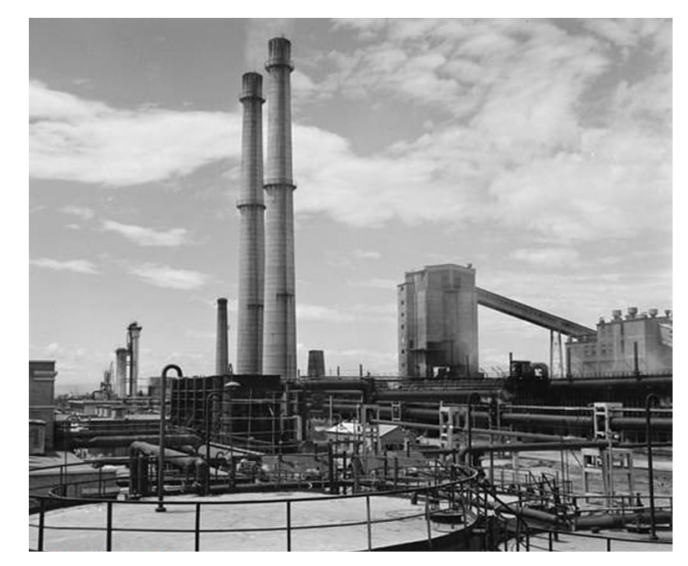

Figure 3. Newly-built coking plant in the 1960s. Source: Beijing Daily.

One of the aims of urban planning was to build functional 'communities' that would provide efficient living and working environments based on the norms for the provision of productive and living conditions. The living quarters (sheng huo qu) with small-scale commercial facilities, infrastructure, and residential communities were consequently built up to allow employees to live in relatively close proximity to their workplace. This kind of industrial area is like a relatively independent small society in the so-called "enterprise-run society (qi ye ban she hui)" system. These areas were especially created for state-owned industrial enterprises that could exercise high-level power and had the ability to mobilize resources and provide social welfare and housing for their employees. In 1960, the Fatou residential office (sub-district office, jie dao) was established, and the district was incorporated into the urban management system. Fatou became an urbanized area through the industrialization process.

By the 1970s, Fatou had formed an area centered on a "Z"-shaped main road named Chemical Industry Road (hua gong $l u$ ), which had both production and living functions (Figure 4). During its peak, many chemical industrial enterprises and institutions agglomerated there, including the Beijing No. 1 chemical plant, Beijing No. 2 chemical plant, Beijing organic chemical plant, No. 1 glass factory, No. 2 glass factory, Beijing coking plant, Beijing Institute of Chemical Reagents, and others. Residential areas such as Fatou Beili, Jinchanli, and Jinchan Beili were established along the Chemical Industry Road. 


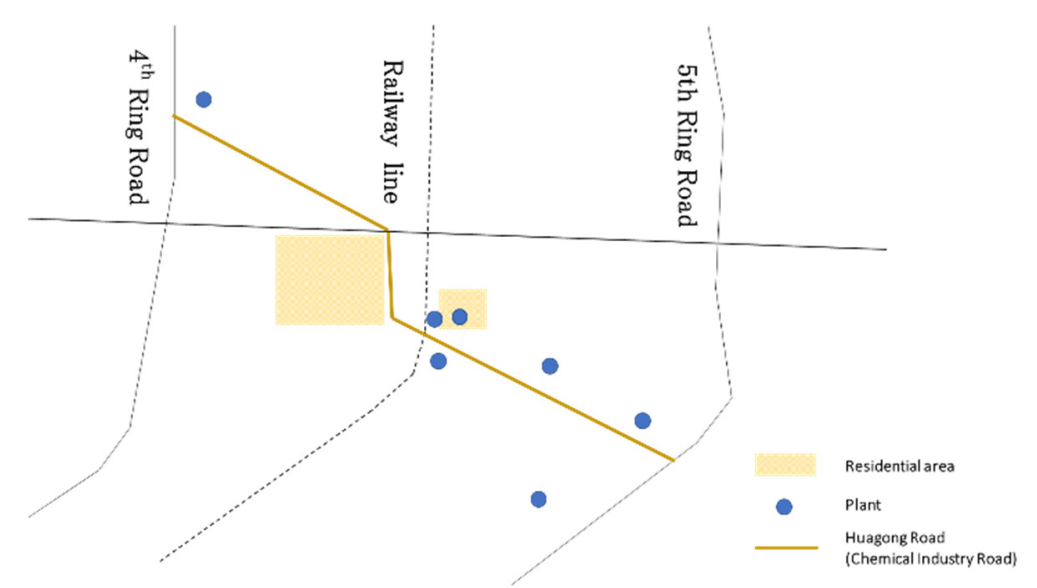

Figure 4. Z-shaped area. Source: According to Chaoyang District Chorography [76].

\section{From In-Migration to Out-Migration}

The gradual arrival of neoliberalism since the 1980s has changed the functions and morphologies of cities like in the other formerly socialist places experiencing transformations [77]. First, the role of cities as production bases was reconsidered. In 1983, the master plan of Beijing reconceptualized the city as a "national political and cultural center" instead of an "economic center", and initiated the decentralization of manufacturing activities away from the central city. This involved the creation of "decentralized conglomerates", which accommodated industrial enterprises that were moved to suburban areas. Particularly polluting or energy-intensive activities were removed from more central areas to give space for a "high-end" sector. Fatou, the industrial area located in the southeast outskirts of the city, initially became a recipient destination for some of those activities.

However, following Beijing's master plan of 1992, the city was repositioned as not only the political and cultural center of China, but also as "a first-class, modern global city." Global cities serve as sites for production and markets of innovation [78]. To increase global competition, high-tech and IT-related industries were deemed to be the new engines of urban growth. This gave rise to the booming construction of industrial parks. Zhongguancun (known as China's Silicon Valley) was officially recognized by the central government in 1988 as the first nation-level "Beijing High-Technology Industry Development Experimental Zone." The Yizhuang Development Area was established in 1992 and promoted to a state-level economic and technological development zone in 1994. A batch of other development zones at different levels were gradually formed. By 1999, for the first time, the proportion of the tertiary industry had exceeded that of the secondary industry.

A salient turning point for Fatou was in the late 1990s when a series of industrial replacement and relocation policies were introduced, such as the policies to "retire the secondary industries within the Third Ring Road while advancing the tertiary industries" (tui er jin san) and "vacate the land within the Fourth Ring Road and upgrade secondary industries after moving out" (tui si jin er). After 1997, when the municipal government set the high-tech industry as the core driver for urban growth, these relocation and regeneration processes sped up. By then, Fatou had become a place of industries' out-migration, and as urban expansion of Beijing progressed, Fatou was administratively incorporated into the central urban area and planned as one of the then ten peripheral residential constellations. With the first green belt established between the constellations and urban core, industry enterprises out-migrated, new residential buildings were constructed, and the landscape and environment were greatly improved. In the process of further globalization, Beijing's flagship project of the Olympic Games was an incentive as well as a state endeavor to speed up Beijing's process of deindustrialization.

Unlike the competition among candidate cities in the US, central government played a decisive role in choosing Beijing to be the host city for the Olympic Games [71]. Consistent with the central state's will to improve its international recognition, the Beijing Olympic Games were financially supported by 
the central government with an estimated 280 billion yuan. Further deindustrialization and industrial relocation processes were bolstered and were the rationale for the environmental consideration and the slogan of 'Green Beijing Olympic Games.' In 2000, a plan to reduce the ratio of industrial land use to $7 \%$ within five years to solve the severe problems of air and noise pollution was instituted. The Beijing Olympic Action Plan (Beijing Aoyun Xingdong Guihua) in 2002 stated that approximately 200 industrial enterprises located in the south-eastern industrial areas and those located within the Fourth Ring Road were required to finish their relocation before 2008. In this context, the Beijing coking chemical plant (a representative enterprise in Fatou) was closed in 2003 and, three years later, relocated to the Hebei Province.

\section{The Formation and Recycling of Urban Brownfields}

The redevelopment agendas related to bringing brownfields back into use have dominated the discourse of sustainable development in post-industrial cities. Since Beijing's Songjiazhuang subway construction worker poisoning incident in 2004, brownfield issues came prominently into the public attention in China. The Beijing municipal government initiated a regulatory framework for environmental assessment and management planning for deserted sites, addressing the risk of historical contamination exposure. Two documents from this framework are of particular importance: Site Environment Assessment Guidelines (January 2007) and Notice on Implementing Soil Environment Assessment for Sites Left from Industry Relocation (July 2007). Environmental assessments have been conducted on more than 50 contaminated sites, among which the Beijing coking chemical plant in Fatou became a target for brownfield remediation after long-term chemical industry production.

After land remediation and environmental assessments, the industrial land renewal process commonly includes several stages, such as adjustment to the land plan, modification of the land contract, land renewal and construction, and land transaction. Brownfield redevelopment in Chinese urban areas is usually embedded in a centralized decision-making process, among which local government, state-owned enterprises, and developers are key stakeholders [5]. With regard to recycling, residential redevelopment has emerged as an important option for brownfield reuse, especially for sites with a locational advantage. Institutionally, this recycling and regeneration process of brownfield sites in the Chinese context involves a redeployment of the urban space under SOEs' control to the market. The case of Fatou was a state-led redevelopment process in which the Municipal Land Arrangement and Reserve Center acted as the intermediate agency. In addition, the brownfield regeneration that happened in Fatou was linked with shantytown regeneration in other parts of the city, under which relocated residents from central areas were rehoused in new housing complexes built on regenerated areas in Fatou. This indicates how the Chinese hybrid system provides supportive policies to guarantee a transition from a socialist housing provision to a market operation.

According to a revised land management law of 1998, all administratively allocated land parcels must first be transferred to the municipal government before being released to developers. This has legalized the transfer of exclusive control over state land to local governments [23]. The Municipal Land Arrangement and Reserve Center (MLARC) was established in 2001 as a manager of state-owned land with official authority in the process of the transfer of land use rights.

With the shutdown of the Beijing dyestuff plant in Fatou in 2003, the SOEs started to deal with state-owned assets in the original plant that were allocated through socialist land allocation in the pre-reform era. In 2004, an acquisition agreement (land-transfer contract) between the dyestuff plant and the MLARC was reached to retrieve land use rights from the former user (SOEs). After primary development (including demolition, infrastructure construction), the land parcel was reserved in the municipal land inventory. Being aware of the development cost, the MLARC organized an open-land auction and public tender, while second developers (construction developers) were asked to bid for the land parcel and to pay official rates for the transfer of land use rights. At the same time, the MLARC, as the intermediate owner of the industrial site, continued to provide public obligations. 
After the plan was adjusted, the land use of this parcel was determined by the planning commission in 2009 for a capped-price housing (xian jia fang) program, which provides subsidized housing to applicants with some conditions. The capped-price housing program is part of the public housing provision system in the post-reform era and embodies an attempt of the socialist state to balance efficiency and social equity. A series of housing reforms launched in the 1980s radically changed the socialist housing provision system of the pre-reform era, in which housing was controlled by work units or municipal housing authorities as social welfare with socialist ideologies. The previous employees of the dyestuff plant used to live in housing around their workplace obtained through a work-unit system. Some of the workers sacrificed their whole lives for this plant and established strong emotional bonds, as well as a sense of belonging, to the plant and the place. In the transition from a member of a workplace (dan wei ren) to a citizen in a society (she hui ren), employees are now provided with an in-kind or monetary compensation from their previous employer (SOEs). When the compensation agreement is reached, employees can receive extra subsidies when purchasing housing in Shuanghe Jiayuan (the residential unit built on the original dyestuff plant, their workplace, see Figure 5). According to the capped-price housing policy that targeted low-to-middle-income urban households (hukou), eligible applicants can apply for a house for $7400 \mathrm{yuan} / \mathrm{m}^{2}$ (in 2009), while original employees can receive a reduced price of $5800 \mathrm{yuan} / \mathrm{m}^{2}$ and can also receive an extra $2800 \mathrm{yuan} / \mathrm{m}^{2}$ subsidy from the dyestuff plant.

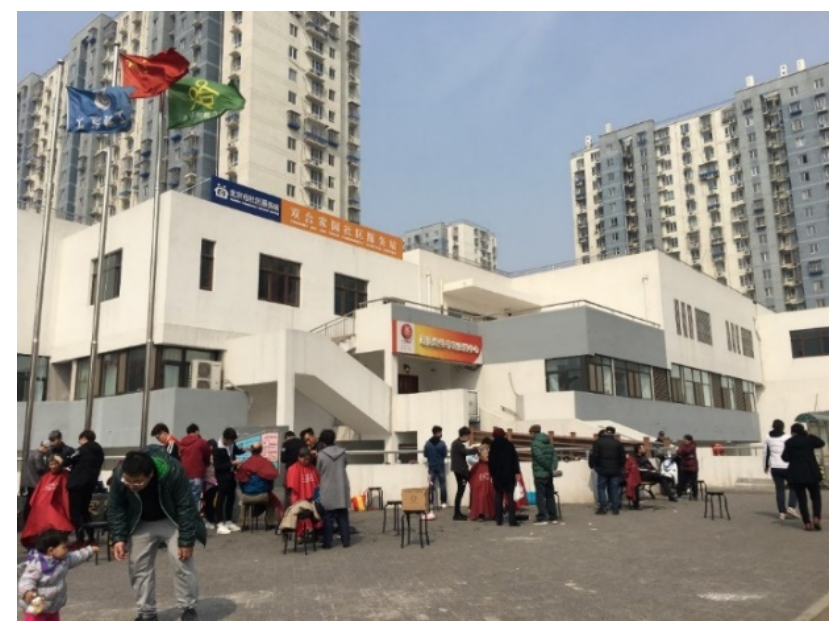

Figure 5. Shuanghe Jiayuan Community. Photo by Nyuying Wang.

The Beijing coking plant ceased its production in 2006, and the main factory area (red area in Figure 6a) with the production equipment was moved to the Hebei Province. Then, part of the site was allocated in 2014 for residential relocation from the Shantytown vacation program surrounding the Temple of Heaven. This cross-community program was instituted to conserve heritage and as part of the national state's obligation under the World Heritage Conventions to maintain and rehabilitate the outer wall of the temple (tan qiang) by 2030. The Temple of Heaven (situated in the south-eastern part of central Beijing, next to the south end of the Beijing central axis) was included in the World Cultural Heritage Sites list in 1998. According to the "integrity" principle (the wholeness and intactness of the natural and/or cultural heritage and its attributes), shanty buildings in this area (established since the 1960s due to housing shortages) must be removed. Therefore, the municipal government started to negotiate with the residents living there and gave them subsidies to relocate. Part of the compensation policy included purchasing housing in the Yanbao Qidong residential unit (see Figure 6c) in Fatou at a discounted price. 


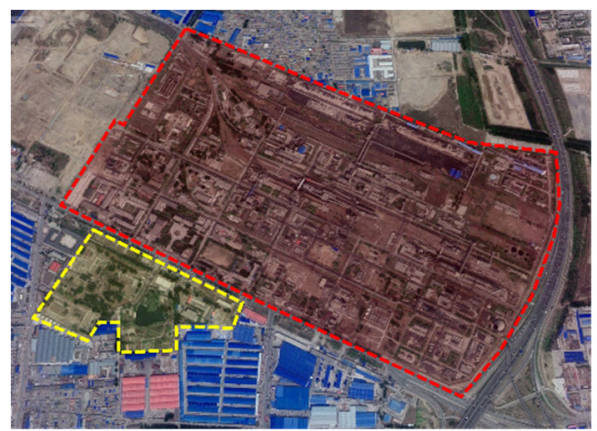

(a) Before regeneration (2010)

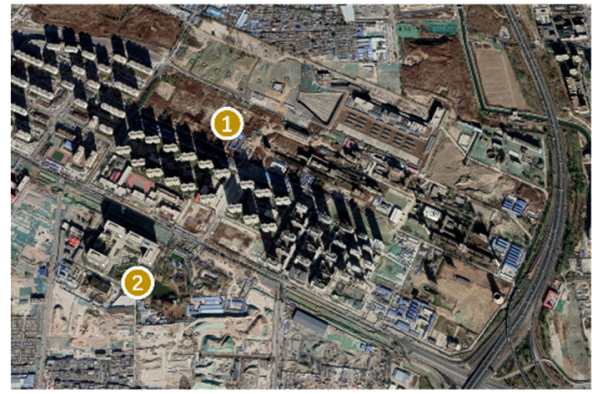

(b) After regeneration (2018)

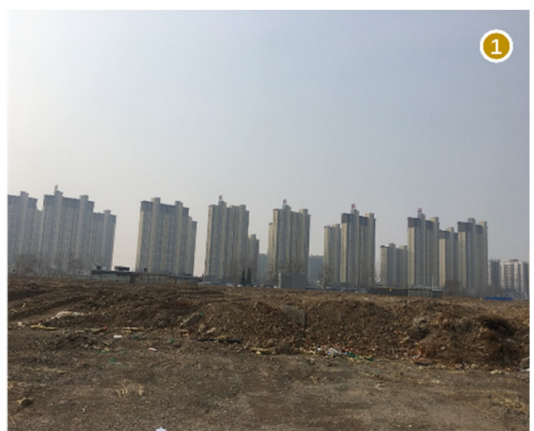

(c) Yanbao Qidong residential community

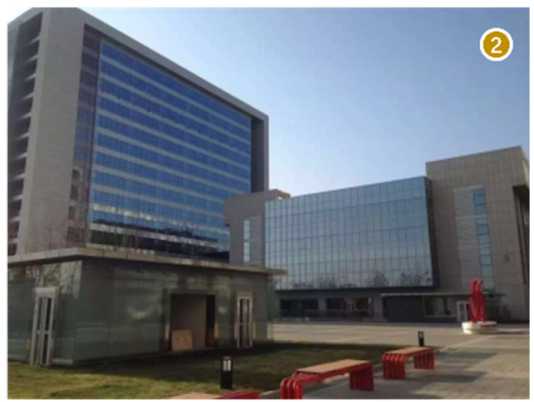

(d) Jiao'ao Office building

Figure 6. Landscape changes at the coking plant brownfield site. (a) and (b) Landscape dynamics from 2010 to 2018; (c) Yanbao Qidong residential unit; (d) Jiao'ao Office Building. Source: Google Earth and photo by Nyuying Wang.

However, the southern part of the coking plant (yellow in Figure 6a), in which the office and service sectors used to be located, did not move with the factory and keeps its industrial function in an upgraded way. On the original site, the Jiao'ao office building was built (see Figure 6d, Figure 7) in 2015 as a technology research and development sector. This building was also incorporated into the Zhongguancun industrial park, locating incubators for creative and technology industries.

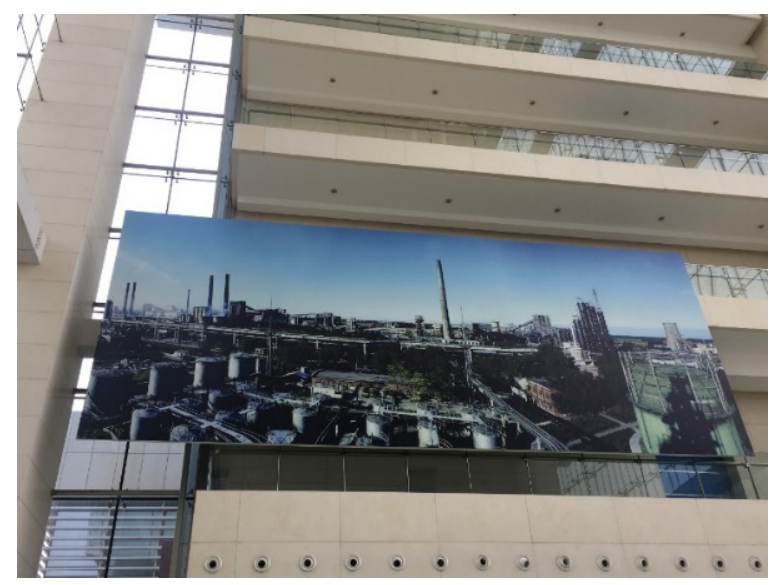

Figure 7. Bird's-eye view of the coking plant (photo in ground floor of Jiao'ao Office Building).

Heritagization is another way to utilize brownfield sites, especially those with historical significance. As the awareness of heritage protection grows in China, so has the interest in it. For example, the Wuxi forum on the conservation of China's cultural heritage, organized by the State Administration of Cultural Heritage in 2006, focused on industrial heritage, vernacular buildings, twentieth-century heritage, and cultural landscapes. The government is realizing a vital role that cultural resources play in place-remaking. At the same time, old employees have a strong sense of 
attachment to the local infrastructure and appealed for its protection from demolishment. It was reported that during two sessions in 2007, more than 50 municipal NPC deputies (Deputy to National People's Congress) and members of the CPPCC (China People's Political Consultative Conference) were involved in six proposals for industrial heritage resource protection and the reutilization of the Beijing coking chemical plant site. The industrial buildings and structures witnessed the progress and achievement in industrial technology (the success of the first self-designed coking chemical oven in China) over the past 50 years. The plant also held a part of the urban historical memory (as the major energy supply base for the capital city). As a result, the eastern part of the original coking plant parcel was put under protection, and plans were made for it to be an industrial heritage park in the future (See Figure 8). In 2018, this area was included in the first group of industrial heritage sites at the national level for its contribution and status in the socialist capital industrial development phase.

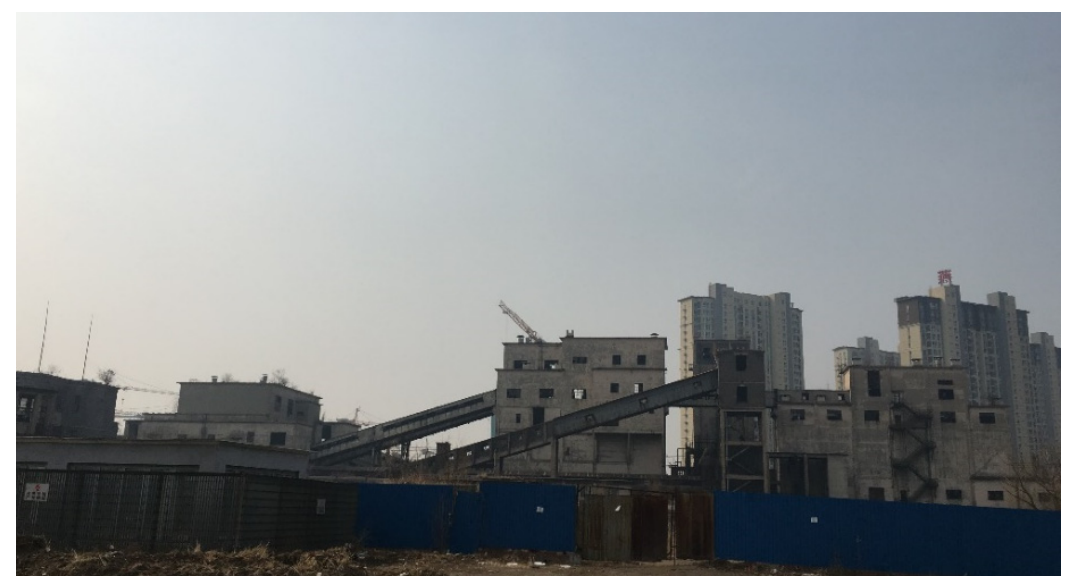

Figure 8. Factory relics and residential building in the back. Photo by Nyuying Wang.

\section{Discussion and Conclusions}

It is easy for an exploration of Chinese urbanism to fall into the dualist binary category of market/state relations. However, the production of space in China does not simply follow a market mechanism and convert the spatial legacies of socialist urbanism into neoliberal spaces. We can argue that the narrative of hybridity is better suited to explaining the co-existence of the still-active communist political ideology and the logic of the market economy in the production of urban space. Differently from other post-socialist experiences, the communist political ideology in the Chinese context is still active, despite the fact that neoliberalism has emerged as a powerful operational logic in the political-economic-social landscape. Hybridity outlines the domestication of neoliberalism as a complex and non-linear interplay of neoliberalism with the socialist regime. Hybrid spatiality provides a perspective to contextualize Chinese urbanism, which also echoes the delicate links between spatiality, historicity, and sociality $[79,80]$.

On the one hand, a series of national-level institutional transformations (including land use rights, tax sharing, and welfare provision) have allowed organizational changes on the city level to follow market rules (such as pro-development local state, privatization of danwei, and marketization of welfare provision). In the case of Beijing, the socialist spatial legacy (including its geography of manufacturing enterprises scattered in central urban areas) has lost its inherited purpose and was reorganized into a new spatial system of capitalist-oriented development-basically allowing the market economy to feast on the socialist 'legacy' and twist the latter to its requirements. Here, brownfield formation as a historically specific product of the political choice of a particular economic and geo-institutional regime [53] represents the spatial legacies of socialist urbanism. The redevelopment process marketizes these spatial legacies. The land acquired in the pre-reform era through administrative allocation to SOEs without any charge is, in turn, commodified and transformed from centrally controlled 
production to an economic asset in the post-reform era [63]. Urban development helps the expansion of marketized urban space through "local growth coalition" with SOEs, and land that was formerly locked up by the old regime has been released to the redevelopment market.

On the other hand, active elements of the communist ideology (such as statism and collectivism) continue to apply their highly centralized logic, top-down governance structure, and ideological propositions to shape the city landscape. For instance, the 2008 Beijing Olympic Games involved more than an urban-level entrepreneurial branding, growth seeking, and marketing strategy. There was also a heavy-handed intervention by the Chinese state to construct the city according to its ideological imaginaries. Following the socialist "concentrate energy on major tasks" (ji zhong li liang ban da shi) regime, the national-level resources were reterritorialized and concentrated at the urban-level locality to ensure that Beijing continues to play its role of a model modern-day capital city of the communist China. Furthermore, various forms of state control and intervention measures ensure the continuation of socialist welfare commitments. This active communist ideology is seen in Fatou's case with specific policy regimes, such as subsidy policy for former state-owned employees as a kind of extension of the danwei welfare system. This holds up the transformation from the danwei system into a "totally" marketized welfare provision, a product of the gradualist transition and hybrid institutions, which in turn, guarantees the continuity and stability of social transformations.

Although Fatou's case has its own contextual development trajectory, it shares many commonalities with other brownfield projects in China, especially in terms of formation and redevelopment mechanisms. The municipal state has actively promoted entrepreneurism in urban initiatives through a series of practices, such as a land-banking system and a pro-growth coalition with SOEs and developers. However, Fatou, as a former industrial complex in the capital city, has always had a higher chance to benefit from its position where national-level resources are concentrated. Post-industrialization trends occur first and foremost in China's most developed metropolitan areas, thus causing an uneven geography of urban development nationwide.

Urban brownfield sites thus reflect the complex transformation of urban China; their formation and redevelopment mirror changes in the community-level spatial fabric, urban-level social practices, and national-level institutional arrangements. The re-combination of active socialist political ideology into the operational neoliberal ideology (or the localization of global neoliberalist logic into Chinese institutional settings, economic-political conditions, and cultural ideology) causes the hybridization of spatial processes. We have also provided an analytical framework that combines the multi-level and temporal evolution as a window into the broader understanding of the relationships between evolving ideologies and hybrid spatiality of urban transformations.

Author Contributions: Conceptualization, Z.L., N.W., and O.G.; methodology, Z.L. and O.G.; investigation, N.W.; resources, N.W. and W.C.; writing—original draft preparation, N.W.; writing—review and editing, O.G., N.W., and W.C.; visualization, W.C.; supervision, Z.L. and O.G.; project administration, N.W. and Z.L.; funding acquisition, W.C. and Z.L. All authors have read and agreed to the published version of the manuscript.

Funding: This research was supported by the National Science Foundation of China [No.41901154, No. 41530751], the National Social Science Foundation of China [No. 17VDL008], the Project of Bureau of International Cooperation of the Chinese Academy of Sciences [No.131A11KYSB20170014], the Strategic Priority Research Program (A) of the Chinese Academy of Sciences [No. XDA19040403], the Second Tibetan Plateau Scientific Expedition and Research Program (STEP) [No. 2019QZKK1007], and China Scholarship Council [No. 201806010313].

Conflicts of Interest: The authors declare no conflict of interest.

\section{References}

1. Ahmad, N.; Zhu, Y.M.; Shao, J.; Lin, H.L. Stakeholders' perspective on strategies to promote contaminated site remediation and brownfield redevelopment in developing countries empirical evidence from Pakistan. Environ. Sci. Pollut. Res. 2020, 27, 14614-14633. [CrossRef] [PubMed]

2. Longo, A.; Campbell, D. The determinants of brownfields redevelopment in England. Environ. Resource Econ. 2017, 67, 261-283. [CrossRef] [PubMed] 
3. Heberle, L.; Wernstedt, K. Understanding brownfields regeneration in the US. Local Environ. 2006, 11, $479-497$. [CrossRef]

4. Osman, R.; Frantál, B.; Klusáček, P.; Kunc, J.; Martinát, S. Factors affecting brownfield regeneration in post-socialist space: The case of the Czech Republic. Land Use Policy 2015, 48, 309-316. [CrossRef]

5. Liu, Y.; van Oort, F.; Geertman, S.; Lin, Y.L. Institutional determinants of brownfield formation in Chinese cities and urban villages. Habitat Int. 2014, 44, 72-78. [CrossRef]

6. Alberini, A.; Longo, A.; Tonin, S.; Trombetta, F.; Turvani, M. The role of liability, regulation and economic incentives in brownfield remediation and redevelopment: Evidence from surveys of developers. Reg. Sci. Urban Econ. 2005, 35, 327-351. [CrossRef]

7. McCarthy, L. The brownfield dual land-use policy challenge: Reducing barriers to private redevelopment while connecting reuse to broader community goals. Land Use Policy 2002, 19, 287-296. [CrossRef]

8. BenDor, T.K.; Metcalf, S.S.; Paich, M. The dynamics of brownfield redevelopment. Sustainability 2011, 3, 914-936. [CrossRef]

9. Letang, S.J.; Taylor, R. Community perception of redevelopment changes and its impact on brownfields redevelopment success. OIDA Int. J. Sustain. Dev. 2012, 5, 21-42.

10. Atkinson, G.; Doick, K.J.; Burningham, K.; France, C. Brownfield regeneration to greenspace: Delivery of project objectives for social and environmental gain. Urban For. Urban Green. 2014, 3, 586-594. [CrossRef]

11. Dixon, T.; Adams, D. Housing supply and brownfield regeneration in a post-barker world: Is there enough brownfield land in England and Scotland? Urban Stud. 2008, 45, 115-139. [CrossRef]

12. De Sousa, C.A. Measuring the Public Costs and Benefits of Brownfield versus Greenfield Development in the Greater Toronto Area. Environ. Plan. B Plan. Des. 2002, 29, 251-280. [CrossRef]

13. De Sousa, C.A. Unearthing the Benefits of Brownfield to Greenspace Projects: An Examination of Project Use and Quality of Life Impacts. Local Environ. 2006, 11, 577-600. [CrossRef]

14. Woo, A.; Lee, S. Illuminating the impacts of brownfield redevelopments on neighboring housing prices: Case of Cuyahoga County, Ohio in the US. Environ. Plan. A 2016, 48, 1107-1132. [CrossRef]

15. Bacot, H.; O'Dell, C. Establishing indicators to evaluate brownfield redevelopment. Econ. Dev. Q. 2006, 20, 142-161. [CrossRef]

16. Yang, Y.C. Chinese cities in transition: Mixed spatial structure produced by a hybrid transitional model. Geogr. Res. 2015, 34, 2021-2034. (In Chinese)

17. Golubchikov, O.; Wolfe, S.D. Russia and the politics of extraverted urbanism in the 2014 Winter Olympics and the 2018 World Cup. In Sport, Statehood and Transition in Europe: Comparative Perspectives from Post-Soviet and Post-Socialist Societies; Rojo-Labaien, E., Rodríguez-Díaz, A., Rookwood, J., Eds.; Routledge: London, UK, 2020; pp. 214-232. ISBN 978-0-367-34440-5. [CrossRef]

18. Adams, D.; Disberry, A.; Hutchison, N.; Munjoma, T. Ownership constraints to brownfield redevelopment. Environ. Plan. A 2001, 33, 453-477. [CrossRef]

19. Frantál, B.; Greer-Wootten, B.; Klusáček, P.; Krejčí, T.; Kunc, J.; Martinát, S. Exploring spatial patterns of urban brownfields regeneration: The case of Brno, Czech Republic. Cities 2015, 44, 9-18. [CrossRef]

20. Frantál, B.; Kunc, J.; Nováková, E.; Klusáček, P.; Martinát, S.; Osman, R. Location matters! Exploring brownfields regeneration in a spatial context: A case study of the south Moravian region, Czech Republic. Morav. Geogr. Rep. 2013, 21, 5-19. [CrossRef]

21. Sýkora, L.; Bouzarovski, S. Multiple transformations: Conceptualising the post-communist urban transition. Urban Stud. 2012, 49, 43-60. [CrossRef]

22. Krzysztofik, R.; Tkocz, M.; Sporna, T.; Kantor-Pietraga, I. Some dilemmas of post-industrialism in a region of traditional industry: The case of the Katowice conurbation, Poland. Morav. Geogr. Rep. 2016, 24, 42-54. [CrossRef]

23. Hsing, Y.T. The Great Urban Transformation: Politics of Land and Property in China; Oxford University Press: Oxford, UK, 2010.

24. Litt, J.S.; Tran, N.L.; Burke, T.A. Examining urban brownfields through the public health "macroscope". Environ. Health Perspect. 2002, 110, 183-193. [CrossRef]

25. Kunc, J.; Navrátil, J.; Tonev, P.; Frantál, B.; Klusáček, P.; Martinát, S.; Černík, J. Perception of urban renewal: Reflexions and coherences of socio-spatial patterns (Brno, Czech Republic). Geographia Technica 2014, 9, $66-77$.

26. Organisation for Economic Co-operation and Development. Urban Brownfields; OECD: Paris, France, 2000. 
27. Oliver, L.; Ferber, U.; Grimski, D.; Millar, K.; Nathanail, P. The Scale and Nature of European Brownfields. Available online: https://www.researchgate.net/profile/Uwe_Ferber/publication/228789048_The_Scale_and_ Nature_of_European_Brownfield/links/5469e8300cf20dedafd20077/The-Scaleand-Nature-of-EuropeanBrownfield.pdf (accessed on 5 May 2020).

28. Maliene, V.; Wignall, L.; Malys, N. Brownfield regeneration: Waterfront site developments in Liverpool and Cologne. J. Environ. Eng. Landsc. Manag. 2012, 20, 5-16. [CrossRef]

29. Baing, A.S. Containing urban sprawl? Comparing brownfield reuse policies in England and Germany. Int. Plan. Stud. 2010, 15, 25-35. [CrossRef]

30. Rall, E.L.; Haase, D. Creative intervention in a dynamic city: A sustainability assessment of an interim use strategy for brownfields in Leipzig, Germany. Landsc. Urban Plan. 2011, 100, 189-201. [CrossRef]

31. Sparrevik, M.; Ellen, G.J.; Duijn, M. Evaluation of factors affecting stakeholder risk perception of contaminated sediment disposal in Oslo harbor. Environ. Sci. Technol. 2011, 45, 118-124. [CrossRef]

32. Bleicher, A.; Gross, M. Sustainability assessment and the revitalization of contaminated sites: Operationalizing sustainable development for local problems. Int. J. Sustain. Dev. World Ecol. 2010, 17, 57-66. [CrossRef]

33. Svane, Ö.; Wangel, J.; Engberg, L.A.; Palm, J. Compromise and learning when negotiating sustainabilities: The brownfield development of Hammarby Sjöstad, Stockholm. Int. J. Urban Sustain. Dev. 2011, 3, 141-155. [CrossRef]

34. Dannert, É.; Pirisi, G. Rusty Hungary: New Insights in Brownfield Research. Eur. Spat. Res. Policy 2017, 24, 5-22. [CrossRef]

35. Sardinha, I.D.; Craveiro, D.; Milheiras, S. A sustainability framework for redevelopment of rural brownfields: Stakeholder participation at SÃO DOMINGOS mine, Portugal. J. Clean. Prod. 2013, 57, 200-208. [CrossRef]

36. Jigoria-Oprea, L.; Popa, N. Industrial brownfields: An unsolved problem in post-socialist cities. A comparison between two mono industrial cities: Reşiţa (Romania) and Pančevo (Serbia). Urban Stud. 2017, 54, 2719-2738. [CrossRef]

37. Dixon, T.; Pocock, Y.; Waters, M. An analysis of the UK development industry's role in brownfield regeneration. J. Prop. Investig. Finance 2006, 24, 521-541. [CrossRef]

38. Cao, K.; Guan, H. Brownfield redevelopment towards sustainable urban land use in China. Chin. Geogr. Sci. 2007, 17, 127-134. [CrossRef]

39. Collins, F.P. The Small Business Liability Relief and Brownfields Revitalization Act: A Critique. Duke Environ. Law Policy Forum 2002, 13, 303-328.

40. The World Bank. Overview of the Current Situation on Brownfield Remediation and Redevelopment in China. Available online: http://documents.worldbank.org/curated/en/450251468024319815/Overview-of-thecurrent-situation-on-brownfield-remediation-and-redevelopment-in-China (accessed on 5 May 2020).

41. Yin, Y.M.; Liu, Z.G.; Dunford, M.; Liu, W.D. The 798 Art District: Multi-scalar drivers of land use succession and industrial restructuring in Beijing. Habitat Int. 2014, 46, 147-155. [CrossRef]

42. Newton, P.W. Regenerating cities: Technological and design innovation for Australian suburbs. Build. Res. Inf. 2013, 41, 575-588. [CrossRef]

43. Loures, L.; Panagopoulos, T.; Burley, J.B. Assessing user preferences on postindustrial redevelopment. Environ. Plan. B Plan. Des. 2016, 43, 871-892. [CrossRef]

44. United States Environmental Protection Agency. Reuse Possibilities for Brownfield Sites. Available online: https://www.epa.gov/sites/production/files/2019-10/documents/reuse_possibilities_for_brownfield_ sites.pdf (accessed on 5 May 2020).

45. Bäing, A.S.; Wong, C. Brownfield residential development: What happens to the most deprived neighbourhoods in England? Urban Stud. 2012, 49, 2989-3008. [CrossRef]

46. Doick, K.J.; Sellers, G.; Castan-Broto, V.; Silverthorne, T. Understanding success in the context of brownfield greening projects: The requirement for outcome evaluation in urban greenspace success assessment. Urban For. Urban Green. 2009, 8, 163-178. [CrossRef]

47. Ganser, R.; Williams, K. Brownfield development: Are we using the right targets? Evidence from England and Germany. Eur. Plan. Stud. 2007, 15, 603-622. [CrossRef]

48. Navratil, J.; Krejci, T.; Martinat, S.; Pasqualetti, M.J.; Klusacek, P.; Frantal, B.; Tochackova, K. Brownfields do not "only live twice": The possibilities for heritage preservation and the enlargement of leisure time activities in Brno, the Czech Republic. Cities 2017, 74, 52-63. [CrossRef] 
49. Strazzera, E.; Cherchi, E.; Ferrini, S. Assessment of regeneration projects in urban areas of environmental interest: A stated choice approach to estimate use and quasi-option values. Environ. Plan. A 2010, 42, 452-468. [CrossRef]

50. Li, D.S.; Chen, B.Z. The strategy of the re-use of the old industry land in the Yangpu old industry area: From industry Yangpu to Knowledge Yangpu. Urban Plan. Forum 2005, 1, 44-50. (In Chinese)

51. Wang, J. 'Art in capital': Shaping distinctiveness in a culture-led urban regeneration project in Red Town, Shanghai. Cities 2009, 26, 318-330. [CrossRef]

52. Yang, X.K. Industrial heritage tourism development and city image reconstruction in Chinese traditional industrial cities: A web content analysis. J. Herit. Tour. 2017, 12, 267-280. [CrossRef]

53. Golubchikov, O.; Badyina, A.; Makhrova, A. The hybrid spatialities of transition: Capitalism, legacy and uneven urban economic restructuring. Urban Stud. 2014, 51, 617-633. [CrossRef]

54. Golubchikov, O. Interurban development and economic disparities in a Russian province. Eurasian Geogr. Econ. 2006, 47, 478-495. [CrossRef]

55. Golubchikov, O. The urbanization of transition: Ideology and the urban experience. Eurasian Geogr. Econ. 2016, 57, 607-623. [CrossRef]

56. Wu, F.L. How neoliberal is China's reform? The origins of change during transition. Eurasian Geogr. Econ. 2010, 51, 619-631. [CrossRef]

57. Brenner, N.; Theodore, N. Cities and the geographies of "Actually Existing Neoliberalism". Antipode 2002, 33, 349-379. [CrossRef]

58. Harvey, D. A Brief History of Neoliberalism; Oxford University Press: Oxford, UK, 2005; p. 120.

59. Tang, Y.; Kunzmann, K.R. The evolution of spatial planning for Beijing. Inf. Raumentwickl. 2008, 8, 457-470.

60. Bray, D. Social Space and Governance in Urban China: The Danwei System from Origins to Reform; Stanford University Press: California, CA, USA, 2005.

61. Lu, D.F. Remaking Chinese Urban Form: Modernity, Scarcity and Space, 1949-2005; Routledge: New York, NY, USA, 2006.

62. He, S.J.; Wu, F.L. China's emerging neoliberal urbanism: Perspectives from urban redevelopment. Antipode 2009, 41, 282-304. [CrossRef]

63. Zhu, J.M. A Transitional Institution for the Emerging Land Market in Urban China. Urban Stud. 2005, 42, 1369-1390. [CrossRef]

64. Zhang, J.X.; Wu, F.L. Mega-event marketing and urban growth coalitions: A case study of Nanjing Olympic New Town. Town Plan. Rev. 2008, 79, 209-226. [CrossRef]

65. Liu, Z.G.; Zhang, J.Y.; Golubchikov, O. Edge-Urbanization: Land Policy, Development Zones, and Urban Expansion in Tianjin. Sustainability 2019, 11, 2538. [CrossRef]

66. Gu, C.L.; Wei, Y.D.; Cook, I.G. Planning Beijing: Socialist city, transitional city, and global city. Urban Geogr. 2015, 36, 905-926. [CrossRef]

67. Fang, K.; Zhang, Y.C. Plan and market mismatch: Urban redevelopment in Beijing during a period of transition. Asia Pac. View 2003, 44, 149-162. [CrossRef]

68. Wei, Y.D.; Gu, C.L. Industrial development and spatial structure in Changzhou city, China: The restructuring of the Sunan model. Urban Geogr. 2010, 31, 321-347. [CrossRef]

69. Chai, Y.W. From socialist danwei to new danwei: A daily-life-based framework for sustainable development in urban China. Asian Geogr. 2014, 31, 183-190. [CrossRef]

70. Lo, C.P. Socialist ideology and urban strategies in China. Urban Geogr. 1987, 8, 440-458. [CrossRef]

71. Wei, Y.D.; Yu, D.L. State policy and the globalization of Beijing: Emerging themes. Habitat Int. 2006, 30, 377-395. [CrossRef]

72. Gu, C.; Hu, L.; Guo, J.; Cook, I.G. China's urban planning in transition. Proc. Inst. Civ. Eng. Urban Des. Plan. 2014, 167, 221-236. [CrossRef]

73. Gao, J.L.; Chen, W.; Liu, Y.S. Spatial restructuring and the logic of industrial land redevelopment in urban China: II. A case study of the redevelopment of a local state-owned enterprise in Nanjing. Land Use Policy 2018, 72, 372-380. [CrossRef]

74. Yeh, A.G.O.; Wu, F.L. The transformation of the urban planning system in China from a centrally-planned to transitional economy. Prog. Plan. 1999, 51, 167-252.

75. Committee for Editing Beijing Chorography. Beijing Chorography-Volume of Urban and Rural Planning_Planning Chorography; Beijing City Press: Beijing, China, 2009; pp. 160-179. 
76. Chaoyang District Chorography. Available online: http://www.bjchy.gov.cn/chaoyang/qznj/ 8a24f09a24d954020124d95b77900005.html (accessed on 25 October 2019).

77. Golubchikov, O.; Phelps, N.A. The political economy of place at the post-socialist urban periphery: Governing growth on the edge of Moscow. Trans. Inst. Br. Geogr. 2011, 36, 425-440. [CrossRef]

78. Sassen, S. The Global City: New York, London, Tokyo; Princeton University Press: Princeton, NJ, USA, 1991.

79. Lefebrve, H. The Production of Space; Blackwell: Oxford, UK, 1991.

80. Soja, E.W. Thirdspace: Journeys to Los Angeles and Other Real-And-Imagined Places; Blackwell: Oxford, UK, 1996. 